\title{
IMPLIKASI PERKAWINAN CAMPURAN TERHADAP STATUS KEWARGANEGARAAN ANAK
}

\author{
A. Mufti Hidayat \\ Institut Agama Islam Negeri Sunan Ampel, Jl. A. Yani 1 I 7 Surabaya | \\ judulsj@gmail.com
}

\begin{abstract}
This paper discusses about Law No. 12 year 2006, article 6 on the Indonesian citizenship which gives the provisions of dual citizenship status to a child as the implication of the mixed marriage, and analysis of Islamic political jurisprudence perspective toward the provisions of the dual citizenship status. The author concludes that granting the dual citizenship status to a child as the implication of the mixed marriage is nothing but for the sake of enforcing the rights of men, particularly for children. It is so because the child's rights are part of the Human Rights which must be guaranteed, protected, and fulfilled by parents, families, communities, governments, and states. In addition, It is also as a manifestation of the implementation of UUD 1945, article 26 about the citizens' rights. Islamic political jurisprudence judges that the dual citizenship status for a child of the mixed marriage for the reason to uphold Human Rights might be justified. Since Islam also upholds Human Rights. But in respect to a childcare, they follow their mother's citizenship when they have been adult. And when they have already been adult, they have right to choose their nationality. Keywords: Implication, mixed marriage, status, and citizenship.
\end{abstract}

Abstrak: Tulisan ini membahas tentang pasal $6 \cup \cup \mathrm{RI}$ No. 12 tahun 2006 tentang kewarganegaraan RI yang memberikan ketentuan status kewarganegaraan ganda pada anak sebagai implikasi perkawinan campuran, dan analisis perspektif figh siyasah terhadap ketentuan status kewarganegaraan ganda tersebut. Dari hasil penelitian dapat disimpulkan bahwa pemberian status kewarganegaraan ganda pada anak sebagai implikasi perkawinan campuran tidak lain demi menegakkan hak-hak asasi manusia khususnya bagi anak, karena hak anak adalah bagian dari hak asasi manusia yang wajib dijamin, dilindungi, dan dipenuhi oleh orang tua, keluarga, masyarakat, pemerintah, dan negara, sekaligus sebagai wujud implementasi UUD 
1945 pasal 26 tentang hak atas kewarganegaraan. Fiqh siyasah menilai, bahwa status kewarganegaraan ganda bagi anak hasil perkawinan campuran dengan alasan demi menegakkan hak-hak asasi manusia, itu dibenarkan. Karena Islam juga sangat menjunjung tinggi hak-hak asasi manusia. Tetapi sehubungan dengan hadanah (pengasuhan anak), anak mengikuti kewarganegaraan ibunya pada saat anak belum tamyiz (dewasa), dan ketika anak sudah tamyiz (dewasa), anak mempunyai hak memilih kewarganegaraannya.

Kata Kunci: Implikasi, perkawinan campuran, status, dan kewarganegaraan.

\section{Pendahuluan}

Salah satu persyaratan diterimanya status sebuah negara adalah adanya unsur warga negara yang diatur menurut ketentuan hukum tertentu, sehingga warga negara yang bersangkutan dapat dibedakan dengan warga dari negara lain. Pengaturan mengenai kewarganegaraan ini biasanya ditentukan berdasarkan salah satu dari dua prinsip, yaitu prinsip ius soli atau prinsip ius sanguinis. ${ }^{1}$ Yang dimaksud dengan ius soli adalah prinsip yang mendasarkan diri pada pengertian hukum mengenai tanah kelahiran, sedangkan ius sanguinis mendasarkan diri pada prinsip hubungan darah. ${ }^{2}$

Berdasarkan prinsip ius soli, seseorang yang dilahirkan di dalam wilayah hukum suatu negara, secara hukum dianggap memiliki status kewarganegaraan dari negara tempat kelahirannya itu. Negara Amerika Serikat, Inggris dan Perancis menganut prinsip kewarganegaraan berdasarkan kelahiran ini, ${ }^{3}$ sehingga siapa saja yang dilahirkan di negara-negara tersebut, secara otomatis diakui sebagai warga negara. Oleh karena itu, sering terjadi warga negara Indonesia yang sedang bermukim di negaranegara di luar negeri, misalnya karena sedang mengikuti pendidikan dan sebagainya, melahirkan anak, maka status

\footnotetext{
' Moh. Kusnardi, Pengantar Hukum Tata Negara Indonesia, 292.

2 lbid, 293.

${ }^{3}$ Dede Rosyada, dkk, Pendidikan Kewarganegaraan (Civil Education), 77.
} 
anaknya diakui oleh Pemerintah Amerika Serikat sebagai warga negara Amerika Serikat. Padahal kedua orangtuanya berkewarganegaraan Indonesia.

Dalam zaman keterbukaan seperti sekarang ini, kita menyaksikan banyak sekali penduduk suatu negara yang berpergian keluar negeri, baik karena direncanakan dengan sengaja ataupun tidak, dapat saja melahirkan anak-anak di luar negeri. Bahkan dapat pula terjadi, karena alasan pelayanan medis yang lebih baik, orang sengaja melahirkan anak di rumah sakit di luar negeri yang dapat lebih menjamin kesehatan dalam proses persalinan.

Dalam hal ini, negara tempat asal sesorang dengan negara tempat ia melahirkan atau dilahirkan menganut sistem kewarganegaraan yang sama, tentu tidak akan menimbulkan persoalan. Akan tetapi, apabila kedua negara yang bersangkutan memiliki sistem yang berbeda, maka dapat terjadi keadaan yang menyebabkan seseorang menyandang status dwikewarganegaraan atau lebih status kewarganegaraannya (multipatride), bahkan sebaliknya malah menjadi tidak berkewarganegaraan sama sekali (apatride). ${ }^{4}$

Berbeda dengan prinsip kelahiran itu, di beberapa negara, dianut prinsip ius sanguinis yang mendasarkan diri pada faktor pertalian seseorang dengan status orang tua yang berhubungan darah dengannya. Apabila orangtuanya berkewarganegaraan suatu negara, maka otomatis kewarganegaraan anak-anaknya dianggap sama dengan kewarganegaraan orang tuanya itu. Akan tetapi, dalam dinamika pergaulan antar bangsa yang makin terbuka dewasa ini, kita tidak dapat lagi membatasi pergaulan antar penduduk yang berbeda status kewarganegaraannya.

Apalagi kalau terjadi perkawinan campuran yang melibatkan status kewarganegaraan yang berbeda-beda antara pasangan suami dan isteri. Terlepas dari perbedaan sistem kewarganegaraan

${ }^{4}$ lbid, 78 .

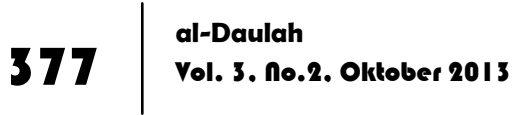


yang dianut oleh masing-masing negara asal pasangan suamiisteri itu, hubungan hukum antara suami-isteri yang melangsungkan perkawinan campuran seperti itu selalu menimbulkan persoalan berkenaan dengan status kewarganegaraan dari putera-puteri mereka.

Dengan cara pertama, status kewarganegaraan seseorang ditentukan karena kelahirannya. Siapa saja yang lahir dalam wilayah hukum suatu negara, terutama yang menganut prinsip ius soli sebagaimana dikemukakan di atas, maka yang bersangkutan secara langsung mendapatkan status kewarganegaraan, kecuali apabila yang bersangkutan ternyata menolak atau mengajukan permohonan sebaliknya. Oleh karena itulah diadakan pengaturan dengan cara kedua, bahwa untuk memperoleh status kewarganegaraan itu ditentukan melalui proses pewarganegaraan (naturalisasi). ${ }^{5}$

Melalui proses pewarganegaraan itu, seseorang dapat mengajukan permohonan kepada instansi yang berwenang, dan kemudian pejabat yang bersangkutan dapat mengabulkan permohonan tersebut dan selanjutnya menetapkan status yang bersangkutan menjadi warga negara yang sah.

Dengan demikian, dapat dikatakan bahwa proses kewarganegaraan itu dapat diperoleh melalui dua cara, yaitu: (i) kewarganegaraan karena kelahiran (ius soli, ius sanguinis) dan (ii) kewarganegaraan melalui pewarganegaraan (naturalisasi).

Fenomena perkawinan campuran ini telah merambah seluruh pelosok Tanah Air dan kelas masyarakat. Globalisasi informasi, ekonomi, pendidikan, dan transportasi telah menggugurkan stigma bahwa kawin campur adalah perkawinan antara ekspatriat kaya dan orang Indonesia. Menurut survey yang dilakukan oleh Mixed Couple Club, jalur perkenalan yang membawa pasangan berbeda kewarganegaraan menikah antara lain adalah perkenalan melalui internet, kemudian bekas teman kerja/bisnis, berkenalan

\footnotetext{
${ }^{5}$ Musthafa Kamal Pasha, dkk, Pendidikan Kewarganegaraan (Civics Education), 24.
} 
saat berlibur, bekas teman sekolah/kuliah, dan sahabat pena. Perkawinan campur juga terjadi pada tenaga kerja Indonesia dengan tenaga kerja dari negara lain. ${ }^{6}$ Dengan banyak terjadinya perkawinan campur di Indonesia sudah seharusnya perlindungan hukum dalam perkawinan campuran ini diakomodir dengan baik dalam perundang-undangan di Indonesia. ${ }^{7}$

Dalam pasal 57 undang-undang No.1 Tahun 1974 tentang Perkawinan, perkawinan campuran didefinisikan sebagai berikut: ${ }^{8}$

"Yang dimaksud dengan perkawinan campuran dalam Undang-undang ini ialah perkawinan antara dua orang yang di Indonesia tunduk pada hukum yang berlainan, karena perbedaan kewarganegaraan dan salah satu pihak berkewarganegaraan Indonesia."

Selama hampir setengah abad pengaturan kewarganegaraan dalam perkawinan campuran antara warga negara Indonesia dengan warga negara asing, mengacu pada UU No.62 Tahun 1958 tentang Kewarganegaraan. Seiring berjalannya waktu UU ini dinilai tidak sanggup lagi mengakomodir kepentingan para pihak dalam perkawinan campuran, terutama perlindungan untuk istri dan anak.

Barulah pada tanggal 11 Juli 2006, DPR mengesahkan Undang-Undang Kewarganegaraan yang baru. ${ }^{9}$ Lahirnya undangundang ini disambut gembira oleh sekelompok kaum ibu yang menikah dengan warga negara asing, walaupun pro dan kontra masih saja timbul, namun secara garis besar Undang-undang baru yang memperbolehkan dwi kewarganegaraan terbatas ini sudah memberikan pencerahan baru dalam mengatasi persoalanpersoalan yang lahir dari perkawinan campuran.

Persoalan yang rentan dan sering timbul dalam perkawinan campuran adalah masalah kewarganegaraan anak. UU

6 http://wnw.mixedcouple.com/articles

$7 \mathrm{lbid}$

${ }^{8}$ Undang-undang Perkawinan di Indonesia, 23.

9 http://www.mixedcouple.com/articles 
kewarganegaraan yang lama menganut prinsip kewarganegaraan tunggal, sehingga anak yang lahir dari perkawinan campuran hanya bisa memiliki satu kewarganegaraan, yang dalam UU tersebut ditentukan bahwa yang harus diikuti adalah kewarganegaraan ayahnya. Pengaturan ini menimbulkan persoalan apabila di kemudian hari perkawinan orang tua pecah, tentu ibu akan kesulitan mendapat pengasuhan anaknya yang warga negara asing.

Berdasarkan UU No. 62 Tahun 1958 tentang Kewarganegaraan, anak hanya mengikuti kewarganegaraan ayahnya, namun berdasarkan UU No. 12 tahun 2006 tentang Kewarganegaraan anak akan memiliki dua kewarganegaraan. Hal ini yang melatarbelakangi penulis, melalui skripsi ini, untuk mengetahui sebab terjadinya kewarganegaraan ganda atas anak hasil perkawinan campuran.

Di sisi lain, kewarganegaraan dalam sistem politik Islam (fiqh siyasah) diklasifikasikan menjadi dua macam, yaitu kaum muslim dan kaum zimmi. ${ }^{10}$ Kaum muslim adalah semua kaum yang beriman dan merupakan penduduk asli suatu negara Islam, atau berdomisili di negara Islam, sedangkan zimmi adalah semua kaum non-Muslim yang bersedia tetap setia dan taat kepada negara Islam yang dijadikan tempat tinggal untuk mencari nafkah, tanpa memperdulikan di negara mana mereka dilahirkan. ${ }^{11}$

Di sisi lain itu, anak harus mendapatkan pengasuhan yang berorientasi pada perlindungan dan pendidikan anak. Pengasuhan anak tersebut merupakan kewajiban orang tua melakukan pengasuhan kepada anak mereka sejak kehadiran anak di dunia sampai tamyiz (usia dewasa) yang disebut hadanah, terutama bagi seorang ibu. Padahal anak tersebut mempunyai kewarganegaraan ganda.

Hal ini menimbulkan pertanyaan, bagaimana konsep kewarganegaraan dalam fiqh siyasah apabila dijadikan landasan

\footnotetext{
${ }^{10}$ Abul A'la Al-Mawdudi, Hukum dan Konstitusi Sistem Politik Islam, 269.

"I Ibid
} 
untuk menilai konsep kewarganegaraan di Indonesia khususnya terhadap status anak berkewarganegaraan ganda.

\section{Perkawinan Campuran}

1. Pengertian Perkawinan Campuran

Perkawinan menurut UU No.1 tahun 1974 tentang perkawinan adalah ikatan lahir batin antara seorang pria dengan seorang wanita sebagai suami istri dengan tujuan membentuk keluraga (rumah tangga) yang bahagia dan kekal berdasarkan Ketuhanan Yang Maha Esa. ${ }^{12}$

Sedangkan perkawinan campuran menurut pasal $57 \mathrm{UU}$ tersebut adalah perkawinan antara dua orang yang di Indonesia tunduk pada hukum yang berlainan, karena perbedaan kewarganegaraan dan salah satu pihak berkewarganegaraan Indonesia. ${ }^{13}$ Artinya, satu pihak berkewarganegaraan Indonesia dan pihak yang lain berkewarganegaraan Asing. Perkawinan campuran harus berdasarkan pada hukum perdata internasional dan memenuhi syarat formalitas sesuai dengan hukum Republik Indonesia serta memenuhi syarat materiil hukum negara yang bersangkutan.

Perkawinan seorang warga negara asing (WNA) dengan warga negara Indonesia (WNI) yang beragama Islam dilakukan dihadapan Kantor Urusan Agama (KUA) di wilayah domisili pengantin wanita yang kemudian dikeluarkan akta nikah. Berbeda dengan perkawinan seorang non-Islam, perkawinan didaftarkan di Kantor Catatan Sipil yang kemudian akan dikeluarkan surat tanda bukti pelaporan perkawinan dari Kantor Catatan Sipil untuk dipergunakan di luar negeri.

\section{Perkawinan Campuran Beda Agama}

Sistem hukum Indonesia masih menerapkan perlakuan yang berbeda antara perkawinan antar sesama muslim dengan yang

\footnotetext{
12 Undang-Undang Perkawinan di Indonesia, 5.

13 Ibid., 23.
} 
non muslim. UU No. 1 Tahun 1974 menerapkan prosedur yang lebih simpel bagi pasangan muslim karena perkawinan mereka langsung dinyatakan sah begitu dikeluarkannya Akta Pernikahan dari Kantor Urusan Agama (KUA). Sementara, untuk pasangan yang non muslim diperlukan satu tahap lagi setelah pengesahan oleh pemuka agama, yakni pencatatan di Kantor Catatan Sipil.

Pada dasarnya, perkawinan campuran adalah perkawinan antara dua orang yang berbeda kewarganegaraan. Dari definisi perkawinan campuran menurut UU Perkawinan ini dapat diuraikan unsur-unsur perkawinan campuran sebagai berikut:

1. Perkawinan antara seorang pria dan seorang wanita;

2. Di Indonesia tunduk pada aturan yang berbeda;

3. Karena perbedaan kewarganegaraan;

4. Salah satu pihak berkewarganegaraan Indonesia.

Tegasnya perkawinan campuran menurut UU ini adalah perkawinan antar warganegara Indonesia dan warganegara asing. Karena berlainan kewarganegaraan, hukum yang berlaku bagi mereka juga berlainan.

a. Syarat-syarat dan pelangsungan Perkawinan Campuran

Apabila perkawinan campuran itu dilangsungkan di Indonesia, perkawinan campuran dilakukan menurut UU Perkawinan (pasal 59 ayat 2).14 Mengenai syarat-syarat perkawinan harus memenuhi syarat-syarat perkawinan menurut hukum masing-masing pihak (pasal 60 ayat 1 ). ${ }^{15}$

Pejabat yang berwenang memberikan keterangan tentang telah dipenuhi syarat-syarat perkawinan menurut hukum masing-masing pihak ialah pegawai pencatat menurut hukum masing-masing pihak (pasal 60 ayat 2). ${ }^{16}$ Apabila pegawai pencatat menolak memberikan surat keterangan itu, yang berkepentingan itu mengajukan permohonan kepada Pengadilan, dan pengadilan memberikan keputusannya. Jika

\footnotetext{
${ }^{14}$ Undang-undang Perkawinan di Indonesia

${ }^{15} \mathrm{lbid}$.

${ }^{16} \mathrm{lbid}$.
} 
keputusan pengadilan itu menyatakan bahwa penolakkan itu tidak beralasan, maka keputusan Pengadilan itu menjadi pengganti surat keterangan tersebut (pasal 60 ayat 3). ${ }^{17}$

Setelah surat keterangan Pengadilan atau keputusan Pengadilan diperoleh, maka perkawinan segera dilangsungkan. Pelangsungan perkawinan dilangsungkan menurut hukum masing-masing agama. Bagi yang beragama Islam, menurut hukum Islam yaitu dengan upacara akad nikah, sedangkan bagi agama yang bukan islam dilakukan menurut hukum agamanya itu. Dengan kata lain supaya dapat dilakukan akad nikah menurut agama islam, kedua mempelai harus beragama islam. Supaya dapat dilakukan upacara perkawinan menurut catatan sipil, kedua pihak yang kawin itu harus tunduk ketentuan upacara catatan sipil. Pelangsungan perkawinan dilakukan dihadapan pegawai pencatat.

Ada kemungkinan setelah mereka memperoleh surat keterangan atau putusan Pengadilan, perkawinan tidak segera mereka lakukan. Apabila perkawinan mereka tidak dilangsungkan dalam masa enam bulan sesudah keterangan atau putusan itu diberikan, maka surat keterangan atau putusan pengadilan itu tidak mempunyai kekuatan lagi (pasal 60 ayat 5). ${ }^{18}$

b. Pencatatan Perkawinan Campuran

Suatu perkawinan dianggap sah, apabila dilakukan menurut hukum masing-masing agama dan kepercayaan. Tiap perkawinan dicatat menurut peraturan perundangundangan yang berlaku guna memperoleh akte nikah,sebagai bukti bahwa perkawinan tersebut adalah sah.

Perkawinan campuran tidak dapat dilaksanakan sebelum terbukti, bahwa syarat-syarat perkawinan yang ditentukan oleh hukum yang berlaku bagi pihak masing-masing telah 
dipenuhi (pasal 60 ayat 1).19 Untuk membuktikan bahwa syarat-syarat tersebut dalam ayat (1) telah dipenuhi sehingga tidak ada rintangan untuk melangsungkan perkawinan campuran, maka menurut hukum yang berlaku bagi pihak masing-masing berwenang mencatat perkawinan, diberikan surat keterangan bahwa syarat-syarat telah dipenuhi (pasal 60 ayat 2). ${ }^{20}$

Perkawinan campuran dicatat oleh pegawai pencatat yang berwenang (pasal 61 ayat 1 UU Perkawinan). Pegawai pencatat yang berwenang bagi yang beragama islam ialah Pegawai Pencatat Nikah atau Pembantu Pegawai Pencatat Nikah Talak Cerai Rujuk. Sedangkan yang bukan beragama islam adalah Pegawai Kantor Catatan Sipil. ${ }^{21}$

Apabila perkawinan campuran dilangsungkan tanpa memperlihatkan lebih dahulu kepada pegawai pencatat surat keterangan atau keputusan pengganti keterangan maka yang melangsungkan perkawinan campuran itu dihukum dengan hukuman kurungan selama-lamanya satu bulan (pasal 61 ayat 2). ${ }^{22}$ Pegawai pencatat yang mencatat perkawinan, sedangkan ia mengetehui bahwa keterangan atau keputusan pengganti keterangan tidak ada, dihukum dengan hukuman kurungan selama-lamanya tiga bulan dan dihukum jabatan (pasal 61 ayat 3$) \cdot{ }^{23}$

\section{Status Kewarganegaraan Ganda atas Anak Hasil Perkawinan \\ Campuran}

Pada dasarnya, tidak hanya anak hasil perkawinan campuran saja yang mempunyai kewarganegaraan ganda, ada "anak" lain yang berpeluang mempunyai status kewarganegaraan ganda

\footnotetext{
${ }^{19} \mathrm{lbid}$.

20 lbid.

${ }^{21}$ Ibid.

$22 \mathrm{lbid}$.

${ }^{23} \mathrm{lbid}$.
} 
menurut pasal 6 UU No. 12 tahun 2006 tentang kewarganegaraan, yaitu:

1. Anak yang lahir dari perkawinan yang sah dari seorang ayah Warga Negara Indonesia dan ibu warga negara asing;

2. Anak yang lahir dari perkawinan yang sah dari seorang ayah warga negara asing dan ibu Warga Negara Indonesia;

3. Anak yang lahir dalam tenggang waktu 300 (tiga ratus) hari setelah ayahnya meninggal dunia dari perkawinan yang sah dan ayahnya warga negara Indonesia;

4. Anak dari seorang ayah atau ibu yang telah dikabulkan permohonan kewarganegaraannya, kemudian ayah atau ibunya meninggal dunia sebelum mengucapkan sumpah atau menyatakan janji setia;

5. Anak Warga Negara Indonesia yang lahir di luar perkawinan yang sah, belum berusia 18 (delapan belas) tahun atau belum kawin diakui secara sah oleh ayahnya yang berkewarganegaraan asing tetap diakui sebagai Warga Negara Indonesia; dan

6. Anak Warga Negara Indonesia yang belum berusia 5 (lima) tahun diangkat secara sah sebagai anak oleh warga negara asing berdasarkan penetapan pengadilan tetap diakui sebagai Warga Negara Indonesia.

Namun, penelitian ini hanya dikhususnya menganalisa dalam hal status kewarganegaraan anak hasil perkawinan campuran saja, dengan melacak akar permasalahan mengapa perkawinan campuran berimplikasi pada status kewarganegaraan anak menjadi ganda.

Menurut pasal 1 angka 1 UU No.23 Tahun 2002 tentang Perlindungan Anak, anak didefinisikan sebagai berikut:24 "Anak adalah seseorang yang belum berusia 18 (delapan belas) tahun, termasuk anak yang masih dalam kandungan." 
Dalam hukum perdata, diketahui bahwa manusia memiliki status sebagai subjek hukum sejak ia dilahirkan. Pasal 2 Kitab Undang-undang Hukum Perdata memberi pengecualian bahwa anak yang masih dalam kandungan dapat menjadi subjek hukum apabila ada kepentingan yang menghendaki dan dilahirkan dalam keadaan hidup. ${ }^{25}$ Manusia sebagai subjek hukum berarti manusia memiliki hak dan kewajiban dalam lalu lintas hukum. Namun tidak berarti semua manusia cakap bertindak dalam lalu lintas hukum. Orang-orang yang tidak memiliki kewenangan atau kecakapan untuk melakukan perbuatan hukum diwakili oleh orang lain.

Berdasarkan pasal 1330 Kitab Undang-undang Hukum Perdata, mereka yang digolongkan tidak cakap adalah mereka yang belum dewasa, wanita bersuami, dan mereka yang dibawah pengampuan. ${ }^{26}$ Dengan demikian, anak dapat dikategorikan sebagai subjek hukum yang tidak cakap melakukan perbuatan hukum. Hanya saja, seseorang yang tidak cakap karena belum dewasa diwakili oleh orang tua atau walinya dalam melakukan perbuatan hukum.

Meskipun demikian, anak tetap dapat dikategorikan sebagai subjek hukum yang sama-sama mempunyai hak, salah satunya adalah hak kewarganegaraan. Setiap anak berhak untuk dapat hidup, tumbuh, berkembang, dan berpartisipasi secara wajar sesuai dengan harkat dan martabat kemanusiaan, serta mendapat perlindungan dari kekerasan dan diskriminasi.

Oleh karena itu, perlindungan terhadap anak perlu diperhatikan dan dijauhkan dari kehidupan yang diskriminatif. Seperti yang tertuang dalam UU HAM pasal 13 ayat (1) yang bebunyi:

Setiap anak selama dalam pengasuhan orang tua, wali, atau pihak lain mana pun yang bertanggung jawab atas pengasuhan,

\footnotetext{
${ }^{25}$ Sri Susilowati Mahdi, Surini Ahlan Sjarif, dan Akhmad Budi Cahyono, Hukum Perdata; Suatu Pengantar, 21.

${ }^{26}$ Kitab Undang-undang Hukum Perdata
} 
berhak mendapat perlindungan dari perlakuan: (a) diskriminasi; (b) eksploitasi, baik ekonomi maupun seksual; (c) penelantaran; (d) kekejaman, kekerasan, dan penganiayaan; (e) ketidakadilan; dan perlakuan salah lainnya. Perlindungan anak adalah segala kegiatan untuk menjamin dan melindungi anak dan hak-haknya agar dapat hidup, tumbuh, berkembang, dan berpartisipasi, secara optimal sesuai dengan harkat dan martabat kemanusiaan, serta mendapat perlindungan dari kekerasan dan diskriminasi, ${ }^{27}$ terlebih lagi kita hidup dalam negara demokrasi.

Indonesia merupakan negara demokrasi dan prinsip dasar negara demokrasi adalah berdasarkan atas hukum dan menghormati HAM. Inilah yang menjadi dasar lahirnya revolusi Perancis pada 1789. Lahir revolusi ini karena hak asasi masyarakat terbelenggu. Masyarakat merasa disakiti pihak kerajaan atas sikap tertutup dan penindasan.

Anak juga termasuk warga negara yang mengandung arti peserta, anggota atau warga dari suatu negara, yakni peserta dari suatu persekutuan yang didirikan dengan kekuatan bersama, atas dasar tanggung jawab bersama dan untuk kepentingan bersama. ${ }^{28}$ Oleh karena itu, anak juga mempunyai persamaan hak di hadapan hukum. Semua warga negara memiliki kepastian hak, privasi, dan tanggung jawab.

Sejumlah orang di dunia memperjuangkan HAM, termasuk Thomas Jefferson, Presiden AS yang ke-3 (1801 - 1809), yang sejak sebelum menjadi presiden berjuang untuk menghapus perbudakan di negara itu. Dia menentang perbudakan karena manusia diciptakan sama. Manusia diberkati oleh pencipta-Nya dan diberi hak asasi yang tidak boleh diganggu gugat oleh siapa pun. Perbudakan tidak pantas dilakukan oleh bangsa yang menyatakan berbudaya tinggi.

Manusia tidak dapat hidup sesuai martabat dan fitrahnya sebagai manusia. HAM adalah landasan dari kebebasan, keadilan

${ }^{27}$ Muladi, Hak Asasi Manusia, 233.

28 Ibid., 73. 
dan kedamaian. HAM mencakup semua yang dibutuhkan manusia untuk tetap menjadi manusia, baik dari segi kehidupan sipil, politik, ekonomi, social dan budaya. ${ }^{29}$ HAM merupakan sarana perlindungan manusia terhadap kekuatan politik, sosial, ekonomis, kultural, dan ideologis yangakan menindasnya kalau tidak dibendung. ${ }^{30}$

Umat manusia khususnya Indonesia pada tahun 1945 merasa sudah saatnya mengakhiri perang, saling menjajah dan bertekad menciptakan perdamaian. Indonesia sejak memproklamasikan kemerdekaannya, menyatakan diri sebagai negara demokrasi.

Sikap Indonesia yang menyatakan diri sebagai negara yang berdasarkan atas hukum dan menjunjung tinggi HAM, dapat dilihat dari UUD 1945 yang memuat ketentuan tentang penghormatan beberapa aspek HAM yang sangat penting, seperti hak semua bangsa atas kemerdekaan (alenia pertama pembukaan), hak atas kewarganegaraan (pasal 26), persamaan kedudukan semua warga negara Indonesia di depan hukum dan pemerintahan (pasal 27 ayat 1), hak warga negara Indonesia atas pekerjaan (pasal 27 ayat 2), hak setiap warga negara Indonesia atas kehidupan yang layak bagi kemanusiaan (pasal 27 ayat 2) dan hak warga negara atas pendidikan (pasal 31 ayat 1 ). ${ }^{31}$

Berdasarkan atas hal itulah, UU No. 12/2006 tentang Kewarganegaraan RI hadir untuk menggantikan UU No 62/1958 tentang Kewarganegaraan RI yang mengundang banyak polemik dan diskriminatif. HAM menurut Indonesia adalah hak yang melekat pada setiap manusia untuk dapat mempertahankan hidup, harkat dan martabatnya. Dalam mengemban hak tersebut dilakukan secara seimbangantara hak dan kewajiban dan antara kepentingan perorangan dan kepentingan umum.

29 Mansour Fakih, Maria Indrianto, Antonius, Eko Prasetyo, Menegakkan Keadilan dan kemanusiaan: Pegangan untuk membangun Gerakan Hak Asasi Manusia, 40.

${ }^{30}$ Franz Magnis Suseno, Kuasa dan Moral, 46.

${ }^{31}$ UUD 1945 Hasil Amandemen 
Yang menjadi bahan pertimbangan adalah pertama, warga negara merupakan komponen strategis dari suatu negara yang memiliki HAM yang perlu dilindungi dan dijamin pelaksanaannya. Kedua, bangsa dan negara RI berdasarkan Pancasila dan UUD 1945, menjamin potensi dan martabat manusia sebagai kodrat HAM sebagai martabat kepribadian luhur manusia.

Ketiga, UU No 62/1958 sudah tidak sesuai lagi dengan sistem ketatanegaraan dan perkembangan masyarakat. Keempat, bangsa dan negara Indonesia berdasarkan Pancasila dan UUD 1945 menuntut peningkatan pelaksanaan hak dan kewajiban sebagai warga negara Indonesia.

Permasalahan sosiologis dalam pelaksanaan UU No 62/1958 yang perlu disesuaikan dengan perkembangan saat ini adalah masalah diskriminasi. Diskriminasi yang terjadi dalam pelaksanaannya meliputi diskriminasi etnis dan diskriminasi gender.

UU No. 12/2006 ini menganut prinsip umum dan universal yang diakui keberadaannya oleh negara-negara di dunia. Sejumlah prinsip itu antara lain pertama, asas ius sanguinis adalah penentuan kewarganegaraan berdasarkan keturunan. Ius sanguinis, menetapkan kewarganegaraan seseorang ditentukan berdasarkan kewarganegaraan orang tuanya, tanpa mengindahkan di mana ia dilahirkan.

Kedua, asas ius soli, adalah penentuan kewarganegaraan berdasarkan tempat kelahiran seseorang. Dengan kata lain, kewarganegaraan seseorang ditentukan berdasarkan daerah/negara tempat ia dilahirkan. Ketiga, nondiskriminatif. Kewarganegaraan Indonesia tidak membedakan perlakuan antar warga negara, yang didasarkan perbedaan suku, ras, agama, golongan dan gender.

Keempat, penghormatan terhadap HAM. Kewarganegaraan Indonesia menghormati hak asasi pada umumnya dan hak warga negara pada khususnya yang tercantum dalam peraturan perundangan di Indonesia. Deklarasi PBB mengakui, bahwa di 
semua negara di dunia ada anak-anak yang hidup dalam kesulitan dan membutuhkan perhatian khusus. Diantaranya adalah menghormati hak anak dan mempertahankan identitasnya termasuk kewarganegaraannya, nama dan hubungan keluarga sebagaimana yang diakui oleh undang-undang tanpa campur tangan yang tidak sah (pasal 8 ayat 1 ). ${ }^{32}$

Kelima, persamaan di muka hukum dan pemerintahan. Setiap warga negara Indonesia akan mendapat perlakuan yang sama dihadapan hukum dan pemerintahan dalam pelayanan bidang kewarganegaraan dan kependudukan. Keenam, mencegah terjadinya apatride (tanpa kewarganegaraan) dan bipatride (kewarganegaraan ganda).

Oleh karena itu, pada dasarnya kewarganegaraan ganda tidaklah ada dalam UU No. 12/2006 tentang kewarganegaraan ini, hanya dikhususkan bagi anak hasil perkawinan campuran, baik perkawinan itu dilaksungkan antara wanita warga negara Indonesia dengan pria warga negara asing atau seorang pria warga negara Indonesia dengan seorang wanita warga negara asing.

Namun, kewarganegaraan ganda tersebut tidak selamanya dimiliki oleh anak hasil perkawinan campuran. Karena ketika anak sudah berusia 18 tahun, anak tersebut disuruh memilih kewarganegaraannya, apakah dia ikut kewarganegaraan ayahnya ataukah ibunya. Artinya, tetap tidak akan terjadi kewarganegaraan ganda dalam sitem kewarganegaraan di Indonesia, kecuali hanya sementara.

Pemberian status kewarganegaraan ganda pada anak tersebut tidak lain demi menegakkan hak-hak asasi manusia khususnya bagi anak, karena hak anak adalah bagian dari hak asasi manusia yang wajib dijamin, dilindungi, dan dipenuhi oleh orang tua, keluarga, masyarakat, pemerintah, dan negara, sekaligus sebagai

${ }^{32}$ Darwan Prinst, Hukum Anak Indonesia, 107. 
wujud implementasi UUD 1945 pasal 26 tentang hak atas kewarganegaraan.

\section{Perspektif Fiqh Siyasah tentang Status Kewarganegaraan Ganda atas Anak Hasil Perkawinan Campuran}

Kewarganegaraan Indonesia sangat menghormati hak asasi pada umumnya dan hak warga negara pada khususnya. Karena itulah, status kewarganegaraan ganda diberikan pada anak hasil perkawinan campuran sebagai wujud penghormatan terhadap hak asasi manusia.

Islam juga sangat menjunjung tinggi hak asasi manusia, seperti yang tersebut dalam bab II, bahwa Prinsip-prinsip hak asasi dalam Islam adalah dasar-dasar ajaran yang berkaitan dengan jaminan akan hak yang dimiliki manusia bersamaan dengan kelahiran atau kehadirannya di dalam kehidupam masyarakat tanpa perbedaan atas dasar bangsa, ras, agama, keyakinan, jenis kelamin, dan sebagainya. Hak-hak asasi manusia terdiri dari hak-hak sipil dan politik, hak-hak ekonomi sosial, dan budaya. ${ }^{33}$

Dalam al-Qur'an disebutkan bahwa salah satu prinsip HAM adalah persamaan harkat dan martabat manusia dan tidak dibenarkan adanya perbedaan manusia karena derajat, warna kulit dan bangsa. Disamping itu, prinsip-prinsip politik pemerintahan yang dibangun nabi dalam piagam Madinah, disebutkan bahwa negara Madinah terdiri dari berbagai golongan, baik golongan besar maupun kelompok-kelompok kecil (bani-bani) yang disebut ahl hazili as-sahifah. Artinya, Nabi tidak membedakan antara satu dengan yang lain.

Inti piagam madinah adalah pertama, semua pemeluk agama islam walaupun banyak terdiri dari banyak suku baik pendatang maupun penduduk asli madinah merupakan suatu komunitas. Kedua, hubungan antara sesama komunitas islam dan antara

33 J. Suyuti Pulungan, Prinsip-prinsip Pemerintahan Dalam Piagam Madinah Ditinjau Dari Pandangan Al-Qur'an, 17. 
agama komunitas islam dan komunitas lain didasarkan atas: (a) bertetangga baik; (b) saling membantu dalam menghadapi musuh bersama; (c) membela mereka yang teraniaya; (d) saling menasehati dan konsultasi; dan (e) menghormati kebebasan beragama. Di sisi lain, keberadaan negara dimaksudkan untuk mengayomi kehidupan umat, melayani mereka serta menjaga kemaslahatan bersama (maslahah musytarakah). ${ }^{34}$ Sebagaimana pedoman dalam kaidah fiqhiyah yang berbunyi sebagai berikut:

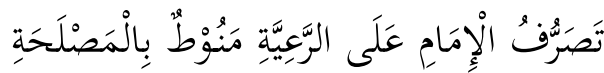

Artinya: "Perintah pemimpin terhadap umatnya membawa kebaikan". 35

Jadi, semua warga negara haruslah mendapat perlakuan yang sama. Semua warga negara memiliki kewajiban dan hak yang sama pula. Sistem kasta atau pemihakan terhadap golongan, ras, jenis kelamin atau pemeluk agama tertentu tidaklah dibenarkan. ${ }^{36}$

Oleh karena itu, persamaan hak dan persamaan di depan hukum (al-musawa) sangatlah dijunjung tinggi dalam Islam. Sebagaimana firman Allah:

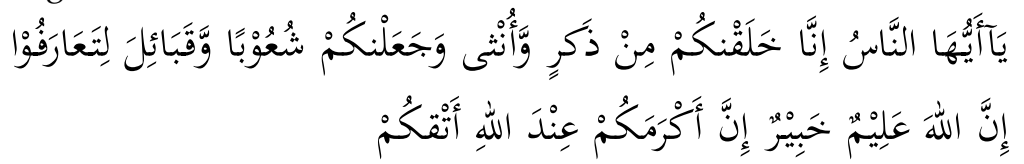

"Hai manusia, sesungguhnya Kami menciptakan kamu dari seorang laki-laki dan seorang perempuan dan menjadikan kamu berbangsabangsa dan bersuku-suku supaya kamu saling mengenal. Sesungguhnya orang yang paling mulia di antara kamu di sisi Allah ialah orang yang paling bertakwa di antara kamu. Sesungguhnya Allah Maha Mengetahui lagi Maha Mengenal." (Q.S. al-Hujurat: $13)^{37}$

\footnotetext{
34 Ibid, 74.

${ }^{35}$ Imam Jalaluddin Abdur Rahman, Al-Asbah Wa al-Nada'ir, 83.

${ }^{36}$ Said Agiel Siradj, Ahlussunnah Wal Jama'ah: Dalam Lintas Sejarah, 78.

${ }^{37}$ Departemen Agama RI, Al-Qur'an dan Terjemahnya, 847.
} 
Rasulullah saw. juga telah menjelaskan dalam salah satu sabdanya:

"Tidak ada orang Arab yang memiliki superioritas terhadap non-

Arab, juga orang non-Arab tidak memiliki superioritas atas orang kulit hitam, atau orang kulit hitam superior tehadap orang kulit putih. Kamu semua adalah anak-anak Adam dan adam diciptakan dari tanah." (Baihaqi dan Bazzaz). ${ }^{38}$

Menurut Islam, Tuhan memberikan kepada manusia hak persamaan ini sebagai hak asasi. Oleh karena itu, tidak seorang pun yang dapat dikenai diskriminasi atas dasar warna kulitnya, tempat kelahirannya, ras atau bangsanya asalnya. ${ }^{39}$

Karena itu, kehidupan manusia adalah hak baginya yang harus dijaga, baik dari segi jasmani maupun ruhani sebab tidak ada seorang pun yang boleh merusak hidupnya, baik tubuhnya maunpun ruhnya.

Menurut pemikiran Ibn Kas \ir, ayat al-Qur'an yang memerintahkan penggunaan kekuatan terhadap non-muslim 2:190-93, 22:39, 4:90, 8:39 dan 61 dan diturunkan di Madinah. Dengan penelitian ini membuktikan bahwa penggunaan kekuatan terhadap non-muslim merupakan fenomena Madinah dengan tujuan mempertahankan diri sampai penyebaran agama Islam ${ }^{40}$

Sesuai dengan konteks historisnya sendiri, syari'ah membatasi penerapan prinsip resiprositas dalam hubungannya dengan non-muslim hanya dapat dipahami dan dilengkapi melalui pertimbangan pengaruh konteks historis saat syariah disusun oleh para ahli hukum perintis pada abad VIII dan IX dari sumber-sumber asli. Dalam konteks ini, wajar ahli hukum membatasi orang lain dalam prinsip resiprositas. Hal ini merupakan gambaran umum dari seluruh tradisi budaya historis dan juga tercermin pada sikap dan kebijakan-kebijakan negara

\footnotetext{
${ }^{38}$ Abul A'la al-Maududi, Hak-hak Asasi Manusia dalam Islam, terj. Human Right in Islam, Bambang Iriana Djajaatmadja, 20.

${ }^{39} \mathrm{lbid}$.

${ }^{40}$ Abdullahi Ahmed An-Na'im, Dekonstruksi Syari'ah, 273.
} 
modern. ${ }^{41}$ Berbeda dengan saat ini, kehidupan sangat pluralistik dan memungkinkan untuk saling menghormati antara satu dengan yang lainnya, sehingga warga negara dapat hidup bersama tanpa adanya permusuhan.

Berkenaan dengan persoalan status kewarganegaraan anak menjadi ganda sebagai implikasi perkawinan campuran, tentunya perlu dilihat dulu dari sisi perkawinan campurannya. Apabila perkawinan campuran tersebut dilakukan sesama orang Islam, sah hukumnya. Sehingga status kewarganegaraan ganda bagi anak hasil perkawinan campuran tersebut, menjadi sah. Tetapi, apabila perkawinan campuran tersebut dilakukan antara orang Islam dengan orang non-Islam, hukum perkawinannya tidaklah sah. Sehingga status kewarganegaraan ganda bagi anak hasil perkawinan campuran tersebut menjadi tidak sah.

Dalam hal kewarganegaraan anak, kedua orang tua wajib melakukan pengasuhan kepada anak mereka sejak kehadiran anak di dunia. Idealitas dalam kewajiban hukum tersebut sudah tentu bukan hal baru, setiap orang tua memahami bahwa berani memiliki anak harus berani mengasuh, menjaga dan mencukupi kebutuhannya. Keyakinan ini sudah tentu harus dimiliki oleh setiap orang tua, walaupun dalam beberapa kasus terdapat orang tua yang melalaikan kewajibannya.

Terutama pengasuhan anak yang berorientasi pada perlindungan dan pendidikan dari orang tua adalah hak yang dimiliki oleh anak asuh dan orang yang mengasuh serta ayah atau penggantinya. Namun jika tidak mungkin merealisasikan hak secara bersamaan, maka yang dijadikan patokan adalah upaya untuk mewujudkan hak anak tanpa memperdulikan hak yang lain. ${ }^{42}$ Aktifitas hadanah tersebut dapat dihentikan jika anak sudah mencapai usia tamyiz yang pada umumnya mencapai umur 7 atau 8 tahun, kemudian disuruh memilih antara kedua orang tuanya yang memenuhi persyaratan.

${ }^{41}$ Ibid, $3 \mid 4$

${ }^{42}$ Wahbah Zuhaili, Al-Figh al-Islam Wa Adillatuhu, Juz VII, 7I. 
Persyaratan pengasuhan anak dalam perspektif hukum Islam yang berafiliasi dengan Syafi'i adalah beragama Islam, jika anak yang diasuh beragana Islam. Untuk memperjelas persyaratan tersebut, Imam Nawawi memberikan beberapa alasan Pertama, tidak ada keuntungan yang didapatkan anak muslim dari pengasuh Non-muslim. Kedua, Non muslim akan menfitnah atau memberikan cobaan terhadap anak asuh. Kalau ini terjadi, maka anak asuh mendapatkan bencana besar. Adapun status anak Nonmuslim yang bersetatus zlimmi dan kebetulan Islam, maka hak pengasuhan anaknya diberikan pada orang Islam. ${ }^{43}$

Sehubungan dengan hadanah (pengasuhan anak), dalam hal kewarganegaraan anak hasil perkawinan campuran, anak mengikuti kewarganegaraan ibunya pada saat anak belum tamyiz (dewasa), tetapi ketika anak sudah tamyiz (dewasa), anak mempunyai hak memilih kewarganegaraannya, mengikuti kewarganeganegaraan ayahnya atau kewarganegaraan ibunya.

\section{Penutup}

Pemberian status kewarganegaraan ganda pada anak sebagai implikasi perkawinan campuran tidak lain demi menegakkan hakhak asasi manusia khususnya bagi anak, karena hak anak adalah bagian dari hak asasi manusia yang wajib dijamin, dilindungi, dan dipenuhi oleh orang tua, keluarga, masyarakat, pemerintah, dan negara, sekaligus sebagai wujud implementasi UUD 1945 pasal 26 tentang hak atas kewarganegaraan.

Fiqh siyasah menilai, bahwa status kewarganegaraan ganda bagi anak hasil perkawinan campuran dengan alasan demi menegakkan hak-hak asasi manusia, itu dibenarkan. Karena Islam juga sangat menjunjung tinggi hak-hak asasi manusia. Tetapi sehubungan dengan hadanah (pengasuhan anak), anak mengikuti kewarganegaraan ibunya pada saat anak belum tamyiz (dewasa),

${ }^{43}$ Al-Nawawi, Al-Majmu', Juz XVIII, 321.

\begin{tabular}{l|l}
395 & al-Daulah \\
Vol. 3. no.2. Oktober 2013
\end{tabular} 
dan ketika anak sudah tamyiz (dewasa), anak mempunyai hak memilih kewarganegaraannya.

\section{Daftar Pustaka}

Arifin, Firdaus. Demokrasi Konstitusional. 29 Juli 2007, bp0,blogger Asfar, Muhammad. Pemilu dan Perilaku Memilih 1955-2004. Surabaya: Pustaka Eureka, 2006.

Basyaib, Hamid, ed. Membela Kebebasan: Percakapakan Tentang Demokrasi. Jakarta: Alvabet dan Freedom Institute, 2006.

Budiardjo, Miriam. Dasar-Dasar Ilmu Politik. Jakarta: PT Gramedia Pustaka Utama, 2004.

Charles, Kurzman, ed. Wacana Islam Liberal: Pemikiran Islam Kontemporer Tentang Isu-Isu Global. Jakarta: Paramadina, 2001.

Ellwein, Warsito. Ambang Batas Pemilu, 10 Juli 2007, www.forumpolitisi.org

Fadl (el-), Khaled Abou. Islam And The Challenge Of Democracy, alih bahasa Gifta Ayu Rasmani dan Ruslani. Islam dan Tantangan Demokrasi. Jakarta: Ufukpress, 2004.

Ginting, Sutradara. Penyederhanaan Sistem Kepartaian secara Demokratis, April 2005, www.forum-politisi.org

Hantayuda. Proyek Stabilisasi Politik, 4 Maret 2008, www.mediaindonesia.com

Iqbal, Muhammad. Figh Siyasah Kontekstualisasi Doktrin Politik Islam. Jakarta: Gaya Media Pratama, 2001.

Jabiri (al-), Muhammad abed. Ad-Dimuqrathiyyah Wa Huquq AlInsan, alih bahasa Mujiburrahman, Syura: Tradisi Partikularitas Universalitas. Yogyakarta: LKiS, 2003.

Jayagukguk, Indra. Cara Penghitungan Perolehan Kursi DPR Pada Pemilu 2009,4 Juli 2008, ijrsh.wordpress.com

Kartawidjaya, Pipit Rochijat. Alokasi Kursi:Kadar Keterwakilan Penduduk dan Pemilih. Jakarta: ELSAM, 2003.

Khaliq, Farid Abdul. Fikih Politik Islam. Jakarta: Amzah, 2005. 
Maududi (al-), Abul A'la. The Islamic Law And Constitution, alih bahasa Asep Hikmat. Hukum dan Konstitusi: Sistem Politik Islam. Bandung: Mizan, 1995.

Na'im (an-), Abdullahi Ahmed. Islam dan Negara Sekuler: Menegosiasikan Masa Depan Syari'ah. Bandung: Mizan, 2007.

Partanto, Pius A. dan M.dahlan al-Barry. Kamus Ilmiah Popular. Surabaya: Arloka, 1994.

Pulungan, Suyuti. Fiqih Siyasah: Ajaran, Sejarah dan Pemikiran. Jakarta: PT RajaGrafindo, t.th.

Qadari, Muhammad. Sekali Lagi Penyederhanaan Partai Politik, 18 Februari 2008, www.suarakarya-online,com

Qardhawi (al-), Yusuf. Min Fighid-Daulah Fil Islam, alih bahasa Kathur Suhardi. Fiqih Daulah Dalam Perspektif Al-Qur'an dan Sunnah. cet. Ke-3, Jakarta: Pustaka al-Kautsar, 1998.

Ranadireksa, Hendarmin. Visi Bernegara: Arsitektur Konstitusi Demokratik (Mengapa Ada Negara Yang Gagal Melaksanakan Demokrasi). Bandung: Fokusmedia, 2007.

Salim, Abdul Mu'in. Fiqih Siyasah: Konsepsi Kekuasaan Politik Dalam Al-Qur'an. Jakarta: PT Raja Grafindo Persada, 1994.

Sanit, Arbi. Perwakilan Politik Di Indonesia. Jakarta: CV Rajawali, 1985.

Simanungkalit, Salomo, eds. Peta Politik Pemilihan Umum 19992004. Jakarta: Penerbit Buku Kompas, 2004.

Soetomo. Ilmu Negara. Surabaya: Usaha Nasional, 1993.

Sukanda, Ahmad. Piagam Madinah dan UUD 1945: Kajian Perbandingan Tentang Dasar Hidup Bersama Dalam Masyarakat Yang Majemuk. Jakarta: UI Press, 1995

Suyatno. Menjelajahi Demokrasi. Yogyakarta: Liebe Book Press, 2004.

Tanjung, Akbar. Sistem Kepartaian Menuju Pemilu 2009, 15 Maret 2008, www.ampi.wordpress.com

Tutik, Titik Triwulan. Pokok-Pokok Hukum Tata Negara Indonesia Pascaamandemen UUD 1945. Jakarta: Prestasi Pustaka Publisher, 2008. 
UU No. 10 tahun 2008 (tentang pemilu anggota DPR, DPD, DPRD). Bandung: Fokus Media, 2008.

UUD 1945, Sektretariat Jendral MPRI, 2006

Zaidan, Abdul Karim, et al. Pemilu dan Parpol Dalam Perspektif Syari'ah. Cipta Media, 2003. 